\title{
Hvordan behandle akutt sinusitt?
}

Sinusitt og sinusittliknende sykdom er svært vanlig og medfører mange legebesøk, flest om vinteren. Akutt sinusitt blir diagnostisert oftere hos kvinner enn hos menn. Dette kan skyldes forskjeller i legesøkningsatferd og at kvinner er mer eksponert for barn med øvre luftveisinfeksjoner. I tillegg kan østrogen gi slimhinnefortykkelse, med større risiko for ostial obstruksjon og etterfølgende sinusitt. De fleste tilfeller av sinusitt involverer flere av de paranasale bihulene.

Virale øvre luftveisinfeksjoner og allergisk rhinitt kan føre til slimhinneødem, innsnevring av ostier, økt sekresjon og nedsatt mukociliær aktivitet. Dette gir redusert oksygenkonsentrasjon, økt karbondioksidkonsentrasjon og danning av serøst sekret i sinus. En slik tilstand kalles serøs sinusitt og kan gi beskjedne symptomer. De fleste blir bra uten behandling. Dysfunksjonelt mukociliært system, anatomiske misdannelser, polypper, septumdeviasjon, fremmedlegemer og svulster kan bidra til sinusitt. I noen tilfeller er sinusitt forårsaket av øvre tanninfeksjoner som spres direkte til sinus maxillaris. Akutt bakteriell sinusitt er vanligvis en sekundær infeksjon som følge av ostieobstruksjon forårsaket av en akutt viral øvre luftveisinfeksjon. Forekomst av bakterier og serøst sekret gir gode vekstbetingelser, og bakteriemengden kan vokse raskt.

Diagnosen kan være usikker i allmennpraksis, der man ikke har objektive diagnostiske hjelpemidler. Fire studier fra allmennpraksis har gitt nyttig informasjon om symptomer, tegn og blodprøver som kan bidra til å skille bakteriell sinusitt fra viral sinusitt og virale øvre luftveisinfeksjoner (1). Purulent rhinoré, både som symptom og funn, var assosiert med bakteriell sinusitt i tre av de fire studiene. Tannsmerter var assosiert med bakteriell infeksjon $i$ to. Andre funn var mindre konsistente prediktorer for bakteriell sinusitt. En tofaset sykehistorie med forverring etter innledende forbedring og manglende effekt av slimhinneavsvellende midler var assosiert med bakteriell infeksjon i hver sin studie, men var ikke undersøkt i de andre. Senkningsreaksjon $>10$ og $>20$ for henholdsvis menn og kvinner var assosiert med bakteriell sinusitt i de to studiene der dette ble undersøkt, mens et nivå av C-reaktivt protein $>10$ var assosiert i én studie, men ikke i den andre der dette ble undersøkt. Fordi akutt bakteriell sinusitt vanligvis utvikles som en komplikasjon til virale øvre luftveisinfeksjoner, er det foreslått at en sykdomsvarighet på under sju dager kan brukes som et negativt diagnostisk kriterium.

En norsk studie gir god informasjon om hvordan akutt sinusitt behandles i allmennpraksis (2). Tilstanden utgjør $8 \%$ av alle konsultasjoner for luftveisinfeksjon hos allmennleger. Rundt tre firedeler av disse fører til behandling med antibiotika, vanligst penicillin V, deretter bredspektret antibiotika, vesentlig amoksicillin, makrolider og tetrasyklin. I forhold til gjeldende retningslinjer for behandling får for mange pasienter forskrevet antibiotika. Det er et overordnet mål å redusere antibiotikaforbruket, som i Norge har økt med rundt $50 \%$ etter 1990 (3). Et alternativ som kan være aktuelt i mange kliniske situasjoner, er å skrive ut en vente-og-se-resept. Med en slik resept vil mer enn halvparten av pasientene la være å hente ut antibiotika på apoteket (4).

Pasienter med milde til moderate symptomer forenlig med akutt sinusitt $\mathrm{i}$ under sju dager bør bare gis symptomatisk behandling. Antibiotikabehandling bør forbeholdes dem som har hatt moderate symptomer på bakteriell sinusitt i mer enn sju dager og dem med alvorlige sinusittsymptomer, slik som sterke smerter eller feber over $39^{\circ} \mathrm{C}$. Mer enn halvparten av pasienter med akutt bakteriell sinusitt blir friske uten antibiotikabehandling.

I en oversiktsartikkel er effekten av antibiotikabehandling ved akutt sinusitt oppsummert slik: Hos pasienter med klinisk diagnostisert akutt sinusitt er det ikke påvist signifikant forskjell mellom antibiotika og placebo. Hos pasienter med sinusitt bekreftet ved CT-, røntgenundersøkelse eller bakteriologisk undersøkelse har man i metaanalyser funnet en signifikant forskjell mellom antibiotika og placebo - en samlet forskjell på 7-15\%. Dette innebærer at mellom sju og 15 pasienter må behandles for at én skal bli bra av behandlingen (numbers needed to treat; NNT) (5). Tre metaanalyser har konkludert med at nyere og bredspektrede antibiotika ikke er signifikant mer effektive enn smalspektrede (6). Initial behandling bør derfor være smalspektret antibiotika som virker mot de mest sannsynlige patogener, dvs. Streptococcus pneumoniae og Haemophilus influenzae. I de norske nasjonale faglige retningslinjene er penicillin 1,3 g × 3-4 førstevalg (7). Internasjonalt er resistens hos pneumokokker og $\mathrm{H}$ influenzae en stor utfordring (8). For å unngå resistensutvikling er det derfor viktig å holde forskrivningen av antibiotika ved luftveisinfeksjoner på et så lavt nivå som mulig.

Bruk av lokale kortikosteroider ved akutt sinusitt har vist varierende resultater. I en engelsk studie var det ingen effekt, mens en Cochrane-rapport har vist at hos pasienter med bekreftet sinusitt gir steroider en liten gevinst $(9,10)$.

\section{Morten Lindbæk}

morten.lindbak@medisin.uio.no

Morten Lindbæk (f. 1950) er professor i allmennmedisin ved Universitetet i Oslo, fastlege i Stokke kommune og leder av Antibiotikasentret for primærmedisin.

Ingen oppgitte interessekonflikter.

\section{Litteratur}

1. Lindbaek M, Hjortdahl P. The clinical diagnosis of acute purulent sinusitis in general practice - a review. Br J Gen Pract 2002; 52: 491-5.

2. Gjelstad S, Straand J, Dalen I et al. Do general practitioners' consultation rates influence their prescribing patterns of antibiotics for acute respiratory tract infections? J Antimicrob Chemother 2011; 66: 2425-33.

3. Usage of antimicrobial agents and occurrence of antimicrobial resistance in Norway. Tromsø/Oslo: NORM/NORM-VET, 2010, 2011.

4. Høye S, Frich JC, Lindbæk M. Use and feasibility of delayed prescribing for respiratory tract infections: a questionnaire survey. BMC Fam Pract 2011; 12: 34. 5. Ah-See K. Sinusitis (acute). Clin Evid Online 2008; pii: 0511.

6. de Ferranti SD, loannidis JP, Lau J et al. Are amoxycillin and folate inhibitors as effective as other antibiotics for acute sinusitis? A meta-analysis. BMJ 1998 317: $632-7$

7. Lindbæk M, red. Nasjonale faglige retningslinjer for antibiotikabruk i primærhelsetjenesten. Oslo: Helsedirektoratet, 2008.

8. Goossens H, Ferech M, Vander Stichele R et al. Antibiotic use in Europe and association with resistance: a cross-national database study. Lancet 2005; 365 : $579-87$

9. Williamson IG, Rumsby K, Benge S et al. Antibiotics and topical nasal steroid for treatment of acute maxillary sinusitis: a randomized controlled trial. JAMA 2007; 298: 2487-96.

10. Zalmanovici A, Yaphe J. Intranasal steroids for acute sinusitis. Cochrane Database Syst Rev 2009; nr. 4: CD005149. 